
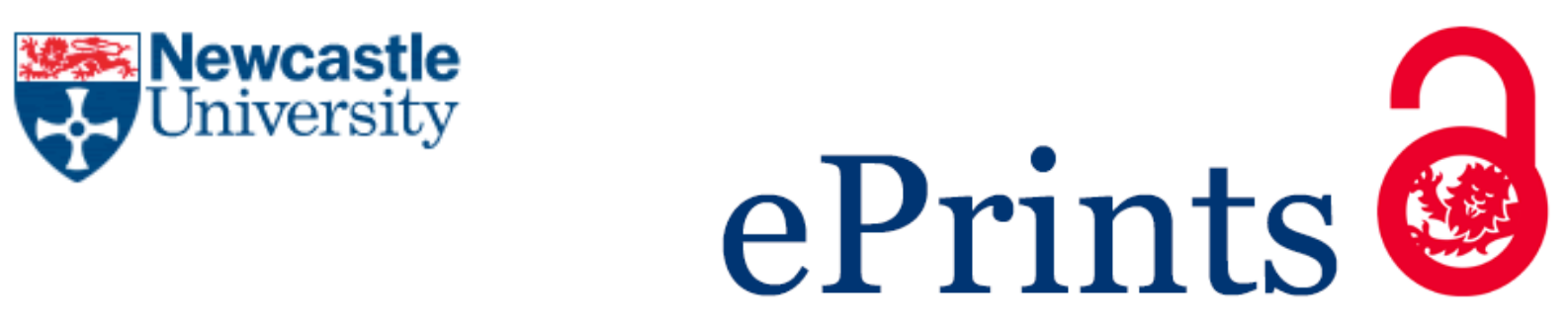

Campbell E.

Policing paedophilia: Assembling bodies, spaces and things. Crime, Media, Culture 2016

DOI: http://dx.doi.org/10.1177/1741659015623598

\title{
Copyright:
}

This is the author's accepted manuscript of an article published in its final definitive form by SAGE Publications, 2016

DOI link to article:

http://dx.doi.org/10.1177/1741659015623598

Date deposited:

$02 / 03 / 2016$

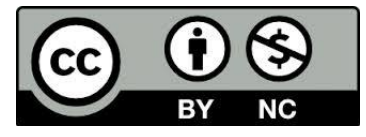

This work is licensed under a Creative Commons Attribution-NonCommercial 3.0 Unported License 


\section{Policing paedophilia: assembling bodies, spaces and things}

Author: Elaine Campbell

Published in Crime, Media, Culture, 2016

DOI: $10.1177 / 1741659015623598$

Online advance access to this article is found at:

cmc.sagepub.com/cgi/reprint/1741659015623598v1.pdf?ijkey=WF2N01lesa0Bg1x\&keytype=finite 


\section{Policing paedophilia: assembling bodies, spaces and things}

\section{Abstract}

In recent years, digital vigilantism, often dubbed 'paedophile-hunting', has grabbed media headlines in the US, UK and Europe. Though this novel style of policing carries no legal or moral authority, it is nonetheless 'taking hold' within a pluralised policing landscape where its effectiveness at apprehending child sex offenders is capturing public attention. While the emergence of digital vigilantism raises normative questions of where the boundaries of citizen involvement in policing affairs might be drawn, this paper is concerned with firstly, how this kind of citizen-led policing initiative comes into being; secondly, how it emerges as an identifiable policing form; and thirdly, how it acquires leverage and makes its presence felt within a mixed economy of (authorised) policing actors, sites and technologies. The paper sets out a detailed case study of a 'paedophile hunter' in action, read through a provocative documentary film, first broadcast on mainstream UK television in October 2014. This lays the groundwork for thinking through the cultural relations of digital vigilantism, and how this proliferating mode of policing practice is engendered and mobilised through affective connectivities, performative political imaginaries, and culturally-mediated dialogical praxis. In seeking an entry point for theorising emergent policing forms and their connectedness to other policing bodies, spaces and things, the paper concludes with a thumbnail sketch of assemblage thinking.

Keywords: plural policing; assemblage theory; paedophilia; digital vigilantism; ontogenesis

\section{Introduction: policing paedophilia}

Paedophilia ${ }^{1}$ looms large in the political and popular imagination of crime, insecurities and existential threats. For Foucault, paedophilia represents `a kind of roaming danger, a sort of

\footnotetext{
1 Throughout the paper, I use the term 'paedophilia' - and related expressions such as 'paedophile' and 'cyberpaedophilia' - with some important caveats. Firstly, 'paedophilia' has no status as a specific offence despite commonplace references to 'convicted paedophiles' in the popular press. Secondly, I am not referring to 'paedophilia' as a psychological disorder - for example, as defined by The American Psychological Association (APA) Diagnostic and Statistical Manual of Mental Disorders (DSM-IV). Thirdly, some of the works cited in the discussion - for example, Yar (2013) - resist the use of this vernacular terminology and more accurately talk of child sexual abuse or child sex offending. However, given the paper's interest in the cultural public sphere, I am
} 
omnipotent phantom' (1988: 281); while Ashenden suggests that it occupies 'a privileged site of anxiety' (2002: 199). The paedophile, argues Thomas, lies at the heart of a 'secular demonology' and has emerged as 'the hate figure of our time' (2005: 1). Routinely figured as 'monsters', 'beasts', 'sex fiends' (ibid), and 'predatory strangers' (Schofield, 2004: 121), the paedophile has become the mainstay of tabloid and broadsheet media (Grealy, 2014; Greer, 2003; Greer and Jewkes, 2005; Jewkes and Wykes, 2012). Moreover, the criminal justice response to child sex offenders across UK and OECD jurisdictions has become increasingly more exclusionary and retributive signalled by the growth of both intensive and extensive punishments, fewer rights, and the proliferation of summary orders and prohibitions (Kemshall and Mclvor, 2004; Thomas, 2005). In short, paedophilia opens up an expansive space for governance, and a diversification of the means and methods for responding to it. In the UK, this is mapped across five key dimensions: first, a robust legislative framework; second, the introduction of statutory checks and disclosures, sex offender registries and notification schemes; third, the establishment of numerous transnational policing organisations representing the voluntary sector (eg: End Child Prostitution, Pornography and Trafficking [ECPAT], and the Association of Sites Advocating Child Protection [ASCAP]), and the private sector (eg: Internet Watch Foundation [IWF], Internet Hotline Providers in Europe [INHOPE]); fourth, the establishment of specialist national level policing units (Child Exploitation and Online Protection Centre [CEOP]); and fifth, the growth of a market of 'antipaedophile software' - such as Net Nanny, Cyber Patrol, Pure Sight, Cyber Sitter, Safe Eyes, Teensafe, and Footprints - see Thomas, 2005, for a more detailed discussion.

From this brief descriptive overview, I want to make two key observations. The first is to acknowledge the extent to which the policing of paedophilia involves a plethora of policing actors working across and within a multi-sited, mixed economy of sectoral interests. This is indicative of what has been variously denoted as a shift to 'plural', 'nodal', 'dispersed', 'distributed', 'multi-lateral', 'post-regulatory' and 'networked' policing, where the cartography of security is marked by its organisational fragmentation and socio-spatial displacements - see Bayley and Shearing, 2001; Clark, 2005; Crawford et al, 2005; Dupont, 2004; Johnston and Shearing, 2003; Jones and Newburn, 2006; Loader, 2000; O'Malley and

following Jewkes and Wykes (2012) in my use of 'paedophilia' and 'paedophile' as expressions which are widely recognisable, and have 'popular, cultural currency in the media and more generally' (2012: 948). 
Palmer, 1996. Indeed, in his exploration of emerging structures and patterns of policing in relation to the exponential rise in cyber-based sex offences, including both adult-oriented and child-centred forms of online sex offending, Yar argues that the governance of cyber-sex crimes does not merely reflect wider trends in the shift towards the networked policing of crime and security, but 'has, in many ways, come to exemplify it' (2013: 488). In a highly textured account of the dynamics and architecture of cyber-policing, he notes the involvement of a plurality of non-state actors, agencies and authorities (Internet Service Providers [ISPs], parents, charitable organisations, social media providers, teachers), who act, variously, in responsibilised, pre-emptive, legally obligated and socially dispersed ways to regulate, monitor, report and disable suspicious online activity and inappropriate sexual communication with children. He writes that this pluralised intervention `effectively bypasses direct involvement of state actors, creating instead a crime control 'assemblage' from which the public police are situated ‘at-a-distance” (2013: 490).

A second observation is to note how far these multi-lateral, dispersed arrangements respond to novel forms and patterns of paedophiliac offending, primarily facilitated by the proliferating use of social media, online communication, and digital technologies which blur any distinction between real and virtual paedophilia. While these technological advances can overwhelm traditional policing's crime control capacities, they also generate new opportunities for the involvement of vigilant and concerned citizens who are encouraged to play a role in the provision of security online (Wall, 2007). It is one thing, however, to enjoin the general public to act preventively by installing protective software, or to promote the reportage of suspicious offline/online behaviour, or even to harness the power of crowdsourcing to assist police investigative work (Crump, 2011; Schneider and Trottier, 2011; Trottier, 2014); but it is a very different proposition to encourage proactive citizen involvement in the policing of paedophilia when it takes the form of digital vigilantism.

In recent years, media attention has been drawn to the activities of numerous digital vigilante groups operating in the UK, the US and Europe. Accompanied by headlines such as 'Vigilante group Dark Justice lure two alleged paedophiles to police' (The Mirror, 8 August 2015), 'The paedophile hunter is putting justice at risk' (The Guardian, 2 October 2014), 'Girl avatar 'Sweetie' catches online predators' (BBC News, 5 November 2013), and 'As Perverted- 
Justice.com battles web pedophiles, some raise concerns over its tactics', (New York Times, 13 December, 2006), the emergence of citizen-initiated cyber-policing has invited a wideranging, critical media commentary which warns against, and rehearses the implications of a drift toward an antediluvian form of justice. Yet, and despite widespread concerns about digital paedophile-hunting, and its methodologies of entrapment, public humiliation and social media exposure, this form of policing has not only continued to flourish and intensify, but (arguably) has also started to connect and align with existing networks of authorised and legitimate policing provision. Such a development moves police-public collaboration well beyond its conventional, and relatively benign remit of providing the (public) police with additional 'eyes and ears'. In so doing, it poses normative questions of where the boundaries of citizen involvement in policing affairs might be drawn.

Jennifer Wood (2006) regards the advent of pluralised models of policing as a democratizing force where the sharing of resources and responsibilities diffuses power across a variegated field of security and governance; while Dupont (2004) has rightly observed that we have not yet settled key political questions of, for example, accountability, due process, rule of law and procedural propriety, in relation to emerging policing networks. If digital vigilantism, in the form of self-styled paedophile hunters, is 'taking hold' within a pluralised policing landscape, then settling such issues remains crucial. However, there are prior questions to be asked here about how this particular style of citizen-led policing comes into being, how it emerges as an identifiable policing form, and how it acquires leverage and makes its presence felt within a heterogeneous assemblage of (authorised) policing actors, sites and technologies. Put another way, digital vigilantism not only creates a space for critical dialogue with conventional accounts of pluralised policing, and how it is assembled, but also casts an investigative spotlight on the social and cultural relations through which new security networks are engendered and mobilised. In the next section I set out a detailed case study of a digital vigilante - a paedophile hunter - 'in action'; this is read through the lens of a provocative documentary film, first aired on the UK's Channel 4 in October 2014, alongside the vociferous media commentary which it generated. This lays the important groundwork for thinking through the conditions of possibility for this kind of policework, and how it emerges less from a set of partnership agreements, resource interdependencies and commercial contracts, but from relations of affect, imaginaries of collective political life, and culturally-mediated, 
dialogical praxis. The paper goes on to theorise this emergence, drawing on assemblage thinking to make sense of digital vigilantism's positioning within, and connectedness to the shifting and uncertain terrain of contemporary policing arrangements.

\section{Assembling bodies, spaces and things}

This is way beyond anything I ever imagined what l'd hoped it would do. But yeah, it's insane, like just one idiot in a bedroom has started something that's really important (Stinson Hunter speaking on The Paedophile Hunter, Channel 4, 2014).

In this quotation, we learn from Stinson Hunter that an idea he took forward as a 'social experiment' (ibid) has opened up a space of possibility for the policing of paedophilia. Hunter formerly known as Kieran Parsons, is a Nuneaton-based 'undercover journalist' who, with a team of two (Grime and Stubbs) pose as young girls (aged 11 to 15 years) by setting up profiles in internet chat rooms to expose grooming. The team exchange texts and messages with men who make contact with the 'girls' online, ensuring that the men are made fully aware of the "girls" underage status. Hunter and his associates monitor the chat room exchanges, collating evidence of explicit messaging, indecent imagery and inappropriate communication as these men engage with who they think is a young girl. Once they have sufficient evidence, the men are confronted with the material and asked to comment on it; the footage, screen shots, images, texts and commentary, are uploaded to Hunter's website - http://stinsonhunter.com/ - disseminated through social media, and the package of evidence, along with a statement is submitted to the (public) police. If the men initiate meetings with the 'girls', Hunter invites them to a 'decoy house' where the confrontation is filmed, and this is added to the evidential material collected via the chat room exchanges. Hunter came to national prominence in October, 2014, when Channel 4 aired The Paedophile Hunter; billed as its most important single documentary of the year' (Conlan, 2014), the one-hour film promised to follow Hunter and his associates as they went about their work in Nuneaton. I say a little more about this below. Hunter is, of course, entitled to ascribe authorship to his own idea, but his style of policing emerges at a time when similarly configured covert practices are already 
underway. In the UK, the activities of the Online Predator Investigation Team (OPIT) (Booth, 2014), Letzgo Hunting (Barford, 2013), Daemon Hunter (Booth, 2013), and Dark Justice (Batchelor, 2015), have come to public attention in the UK press, not only with regards to their (alleged) instrumental role in the detection and conviction of paedophiles, but also as linked to a number of suicides and 'broken lives' which have followed the public exposure of men with suspected paedophiliac proclivities (Booth, 2013). Moreover, these UK examples are part of an emerging international trend which has seen a similar modus operandi developed by the Perverted-Justice Group in the US, which used the medium of a reality TV show, To Catch a Predator, to showcase their methods ${ }^{2}$. Similarly, Tatort Internet, aired in Germany in 2010 on the tabloid channel RTL2, featured an actor, impersonating a teenager, engaged in chat room exchanges with men searching for sex with minors. Any subsequent meetings with the 'girl' were staged as a secretly filmed confrontation with a journalist posing as her mother'. Moreover, in November 2013, the computer-generated 'Sweetie' made global headlines when the Dutch children's aid organisation, Terres des Hommes, revealed its use of an online child avatar to unmask men willing to pay the '10 year old Filipina girl' to engage in sexual acts in front of a webcam (Williams, 2013) ${ }^{4}$. It could be argued, then, that Stinson Hunter's idea - albeit subjectively experienced in the seclusion of his bedroom connects with an emergent policing assemblage of 'digital vigilantism', and through that process asks questions of - and proffers answers to - what is, or can be assembled in the name of the 'policing of paedophilia'.

\section{Assembling policing bodies}

I use the term 'digital vigilantism' with some qualification. Indeed, how Hunter and his activities are named and signified has implications to his positioning as a 'police actor'. We can note, for example, how Hunter's self-proclaimed identity as an 'undercover journalist' not only distances him from the more evocative term of 'vigilante', but also extricates him from

\footnotetext{
2 The show was abandoned in 2007 following the suicide of a Texan lawyer, who shot himself during filming when he was confronted at home by police (Barford, 2013).

3 Tatort Internet came under fire from child protection groups, the justice minister and lawyers, following the disappearance of a 61 year old suspected paedophile; exposed by the programme, it was feared that he had either gone underground or had taken his own life (Connolly, 2010).

4 During the ten week operation, Terres des Hommes asserted that over 20,000 'predators' had contacted Sweetie to request webcam sex performances; using social media and other sources of information gleaned from the online exchanges, the charity claimed to have identified 1000 alleged sex offenders (including one woman), from 71 different countries (Crawford, 2013; Williams, 2013).
} 
any sense of acting with 'unlawful authority'. Indeed, the language which circulates the media coverage of Stinson Hunter suggests, at the very least, how discourse is mobilised within an ontological politics which negotiates the contours of 'authorised policing' and the kinds of policing actors who come to be acknowledged and valued as such. For the most part, commentators remain critical of Hunter's endeavours and discredit him through a range of signifiers, such as 'self-styled paedophile hunter', 'jobless former jailbird' (Methven, 2014), and 'controversial web vigilante' (Conlan, 2014). At the same time, a vocabulary of 'entrapment', 'sting', 'target', 'subterfuge', and 'hunting' permeates the journalistic discourse and positions his techniques and methods outwith legitimate and acceptable policing practices. However, Hunter's covert methodologies are not at all out of place when juxtaposed with those routinely deployed in the policing of cyber-paedophilia. Indeed, within the documentary film, a retired DC from the Metropolitan Police, Jonathan Taylor, talks openly about the public police's use of 'covert internet investigations' and he recalls how he regularly went online posing as 12 and 13 year old girls. However, his point in relaying this information was not to disqualify Hunter's methods, so much as question his capacity to manage the sheer volume of traffic which these profiles generate. At the same time, the former CEO of the Child Exploitation and Online Centre (CEOP), Jim Gamble, raised concerns within the documentary about Hunter's lack of training and accreditation, noting that while it needed very little training to be 'shooting fish in a barrel' (Channel 4, 2014), it was a task that needed to be reserved for law enforcement. Hugh Davies OBE QC, also commenting in The Paedophile Hunter, argued that 'this really is meant to be the sort of covert operation that is run by the police. The risk is that very important evidence will be lost if it's not the police in control of the operation'. The development of proactive strategies of covert, undercover cyber-policing which makes use of specialist intelligence and technical expertise, and which builds partnerships with ISPs, software developers, the cybersecurity industries, and cross-national private and public policing organisations, has been well documented (Yar, 2006; Wall, 2007; Jewkes, 2010b). As far as Hunter and his 'undercover journalism' is concerned, he cannot be coded within this policing assemblage since he lacks the requisite capacity, training, expertise and infrastructural wherewithal to connect with it. 


\section{Spaces of affect and performance}

There's a growing frustration among the public. Online paedophiles are at epidemic levels - police forces have seized about 300 million child abuse images over the past two years, which shows the scale of it. The feeling that the issue is not being properly tackled by the authorities leads to people trying to get involved themselves. People at home often have more knowledge of the internet than police officers. They think they can add value (Barford, 2013: emphasis added).

These are the words of award-winning investigative journalist, Mark Williams-Thomas, a former detective specialising in child protection and high profile investigations. Interviewed by Vanessa Barford for BBC News, to comment on the emergence of Letzgo Hunting, WilliamsThomas identifies how policing assembles through connectivities of affect, as much as through the acquisition of bespoke credentials, such as training, expertise and organisational capacity. Similarly, Booth (2013: emphasis added) comments that there is an undercurrent of public concern that police are struggling to trap online sex offenders'. Importantly, then, both of these comments embed an affective force of frustration and concern within a discourse of public policing's (perceived) organisational incapacity. The evidence of policing's capacity to effectively manage the risks posed by online paedophilia certainly remains equivocal. There has been wide publicity for 'successful', transnational and multi-sectoral policing operations - such as Operation Cathedral, 1998 (Wall, 2007); Operation Rescue, 2008-11 (CEOP, 2011); Operation Ore (UK)/Operation Avalanche (US), 2006 (Jewkes and Andrews, 2007; Wall, 2007); and the recently reported Operation Notarise which has been described as a 'breakthrough .... in how the NCA (National Crime Agency) for the first time coordinated a major investigation involving each of the UK's 45 (sic) police forces' (Halliday, 2014). These kinds of pronouncements give an illusion of the effectiveness of proactive policing ${ }^{5}$, and it perpetuates the notion of sophisticated and intelligence-led, highly specialist policing which is somehow able to intercept and disrupt the flow of online child sexual abuse traffic. Yet, such interception remains extremely rare. According to Jenkins (2009), most

\footnotetext{
${ }^{5}$ Consider, for example, Operation Rescue (2008-11); this was a 3-year investigation of the paedophile network, boylover.net, and was a co-ordinated operation involving CEOP, Europol, US Immigration and Customs, and the police services of Australia, New Zealand, the Netherlands and Canada. The operation exposed 70,000 members of this online site; it identified 670 suspected paedophiles aged $17-82$ years; 184 arrests were made globally with 33 convictions across 8 countries, which equates to an average of 4 convictions per country (CEOP, 2011). This hardly seems to be the overwhelming success which has been claimed.
} 
arrests relating to cyber-based paedophilia are collateral bonuses arising from, for example, investigations of 'real-world' molestation or abuse; paedophiles using their own credit cards to subscribe to child sex abuse sites, taking computers to be repaired, trading through email, and/or using chat lines for dealing. It is precisely this ambivalence which opens up a space of potentiality, and enables Hunter to position his work at the interstices of policing (in)capacity and public concern about it. In one of his more philosophical moments, he opines:

It's a common misperception that the police do nothing. But it's not that they don't do nothing, it's that they're bound by red tape. It needs like a massive cash injection to the police for the police to be able to do something like this. My intention was to try and get them funded. You know, if we can bring it home what the problem is, somebody somewhere has got to sit down and say well, look, why are the general public doing this, we should be doing this and give them the funding to do it. It shouldn't be down to people like me (Channel 4, 2014)

Hunter's reluctance to be critical of public policing's performance, and his intention to 'get them funded'6 offsets any sense of his work as constituting an antagonistic (or deterritorialising) policing form. Indeed, the documentary maps out very well the material and expressive resources he exploits in ways which assemble his work to align with the component elements of more stable policing assemblages. For example, throughout the film Hunter reminds us of the importance of different kinds of evidence (visual, textual, oral and performative), and the need to preserve it; he demonstrates a working knowledge of the Sexual Offences Act, 2003; he maintains a courteous disposition throughout his 'confrontations' referring to suspected paedophiles as 'sir', and assuring them that there will be no hostilities. This does not professionalise Hunter's practice, but it does position him at some distance from thuggery and violence, and stereotypical assumptions of vigilante actors. He is also attentive to the required demeanour of an 'arrested' person and advises one of his 'targets' to appear less nonchalant on film: 'Obviously, this video's going online; and you're

\footnotetext{
6 In the two days following the airing of The Paedophile Hunter, Hunter raised just under $£ 30,000$ on his Kickstarter page - www.kickstarter.com/projects/stinsonhunter/project-1 At the time of writing, the total has

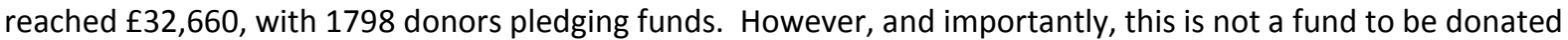
to the police; rather it is to be used to expand his project to different areas of the UK, and parts of the 'wider world' (Wyatt, 2014)
} 
not coming across really well. It's as if you don't really care' (ibid) ${ }^{7}$. All of this is buttressed by the interjected commentary of the documentary's contributing experts - 'that's admissible evidence' (Jim Gamble, ibid); 'in fact, it’s a perfectly standard procedure’ (Hugh Davies, ibid). However, if these aspects of Hunter's policing practice code it as 'policing proper', then other components mark its difference and divergence, and gives flight to new policing dynamics.

\section{Mediating things}

I am referring here to Hunter's arsenal of recording devices and his prolific use of social media to not only disseminate and publicise his work, but also to archive it in digital form. In The Paedophile Hunter, we follow a sequence where Hunter's team capture a screen shot of a man masturbating to whom he believed was a 13 year old girl. Hunter provides a running commentary as he uploads the image to Facebook, complete with the man's personal details, and the evidence of the chat room exchange. Speaking to camera, Hunter explains:

So, that's getting it out there. With Facebook, it's about liking it and commenting on it, and then it just spreads, so that's the good thing about Facebook. As much as I hate

it, I think it's good in the way it forces people to see it. Look, that's got 54 shares ...... in 5 minutes (Channel 4, 2014).

For me, it is Hunter's questionable but unique appropriation of the cultural public sphere which decodes and deterritorialises conventional police-public interaction and reassembles it as a dialogical space of heteroglossia and polyphony. As Denham (2014) notes 'Stinson Hunter set social media alight last night, dividing the country when his vigilante antics were revealed in a Channel 4 documentary'. Moreover, since the Channel 4 film aired, Hunter has appeared as a guest across both radio and television media, and was interviewed for the French Channel, Canal Plus ${ }^{8}$; by Jeremy Vine for BBC's Radio $2^{9}$; he was invited to talk about his self-created role as 'the paedophile hunter' on ITV's This Morning ${ }^{10}$; and he has been profiled by the Express and Star, a West Midlands-based regional newspaper ${ }^{11}$. Jewkes writes

\footnotetext{
7 This particular advice was extended to Lee Middleton, aged 39, who was arrested by the police later that day, and subsequently convicted and sentenced to 3 years imprisonment.

8 See: http://stinson-hunter.com/2014/10/canal-plus-interview-french/

9 See: http://stinson-hunter.com/2014/10/radio-2-interview-jeremy-vine/

10 See: http://stinson-hunter.com/2014/10/stinson-hunter-itv-morning/

11 See: http://stinson-hunter.com/2014/10/express-star/
} 
persuasively on the limits of police-public communication using digital media, and points out how, for the most part, this is restricted to the use of 'first-generation' sites which are primarily designed as a public relations tool 'to promote that force and to disseminate public information' (2010b: 528). Public policing, then, makes little or no use of the dynamic, interactive and transactional capacities of more advanced digital platforms, and misses an important opportunity to generate the kinds of heated debates which have followed Hunter and his particular style of policing work. On the other hand, it is questionable as to whether the affective energy of Hunter's brand of dialogical practice, centering as it does on the communicative power of anger, disgust, shock, and outrage, as well as the use of public humiliation as its deterrent force, assembles the sorts of dialogue which move justice (or policing) forward. This begs the question of whether the emergence of the forms of policing represented by Stinson Hunter, alongside OPIT, Daemon Hunter and Letzgo Hunting, can be (or should be) assembled within the 'extended policing family'. Despite, or perhaps because of their shortcomings, a number of prominent voices have called for their inclusion into the policing fold. For example, Peter Garsden, President of the Association of Child Abuse Lawyers, has been quoted as saying that 'there is so much out there that the police cannot even scratch the surface, so there is an argument for recruiting amateur sleuths' (Johnston and Bartlett, 2014). At the same time, and in the aftermath of the conviction of Peter Mitchell at Derby Crown Court (November 2014), which was set in process by an OPIT 'sting', Jim Gamble (former CEO of CEOP) attacked the 'confused, muddled approach by government', and advocated that 'vigilantes should be brought in from the cold, and incorporated into the public policing portfolio as a volunteer army of a 1,000 'digital detectives" (Booth, 2014). More tellingly, Booth (2013) notes that 'police admit they have been torn over whether to embrace or reject the morally fraught method'; while Dowling comments that:

It's impossible to dismiss Hunter's commitment to his mission, or even his methods the police, after all, employ similar tactics, when they can marshall the resources - but Stinson's attempts to shed light on this issue have taken him to a very dark place, and for an uncomfortable hour, we were obliged to share it with him (Dowling, 2014).

It is not my intention to pass judgement on whether the place in which Hunter finds himself is dark or otherwise. However, Hunter does occupy a place; or, to put it another way, he is 
positioned in what McFarlane describes as a 'problem-space' (2011: 652) which prompts critical reflexivity of not only what the policing of paedophilia in a pluralised regime of governance might entail, but also the socio-cultural relations through which it emerges. What we learn from The Paedophile Hunter is that while this style of digital vigilantism does not sit easily within conventional notions of policing networks, as formed through the structural logics of, say, marketization, civilianisation, neoliberalism, and deregulation (see Bayley and Shearing, 2001 for a fuller discussion), it does form a series of alignments and connections to other policing actors, sites and technologies through relations of affect, performative practices, and processes of cultural mediation. In the next section, I expand on this by contextualising Stinson Hunter's model of policework within an alternative reading of policing configurations, one which foregrounds how the policing of paedophilia is engendered by and mobilised through affective connectivities, performative community action, and the cultural public sphere as much as or, in some ways, to a greater extent than formalised mechanisms such as collaborative agreements, the sharing of intelligence, and private security contracts. In so doing, I sketch out a contrasting vision - a different ontology - of how pluralised policing comes into being in a way which moves us away from accounts which regard policing networks primarily as the outcome of multi-sectoral organisational and policy processes.

\section{Policing paedophilia: cultural conditions of possibility}

I want to preface this section by briefly reflecting on Jim Gamble's comment that Hunter and his ilk should be rescued 'from the cold' and serve as a 'volunteer army of a 1,000 'digital detectives". On the face of it, such a move would certainly provide authoritative oversight, standardisation and accountability to these mushrooming citizen-led practices; at the same time, and as noted above, the public police are keen to publicise the 'successes' of their multisectoral, partnership operations so would not necessarily shy away from their association with such 'voluntary groups', nor from claiming organisational credit for the demonstrable effectiveness of this kind of paedophile hunting ${ }^{12}$. Indeed, as Yar argues, for all the overtures

12 Dan Reed, Director of The Paedophile Hunter, attributes 10 convictions, and the exposure of 60-70 alleged paedophiles to Stinson Hunter. In the same article, he stated that the filmmakers 'did try and obtain figures on how many convictions there had been obtained by Warwickshire police and various police forces as a result of ... covert internet investigations'; however, the force would not supply this information. In the same piece, Hugh Davies OBE QC, who appeared in the film as an expert, admitted that he could not provide any hard evidence of 
to pluralisation and the democratisation of policing arrangements, the potential for alternative (non-state) policing agents/agencies to be absorbed into the public policing fold remains high, especially with regard to the policing of (cyber)paedophilia. He notes, for example, that in the light of the 'intense public concern, anxiety and recurrent moral outrage' (ibid: 491) which online child sex offending generates, the networked governance of cyberpaedophilia is nonetheless re-inscribed within state-centric policing arrangements. He invokes the term 'hierarchies of standing' to denote how the public police remain at the apex of crime control where the perceived seriousness of offences, the dangerousness of offenders, the levels of risk posed, the extent of harm caused, the acute vulnerability of victims, and the clandestine nature of offending, 'drive expectations that they will be subject to urgent and concerted action by state agencies, rather than being delegated to the responsibility of non-state actors' (ibid: 482). Yar is not the first or only commentator to identify the propensity for public policing to retain some level of organisational responsibility over what is an ever-widening, mixed economy of policing actors. As Lister notes of the newly marketised landscape of neighbourhood security providers, the public police are energetically '(re)painting the town blue' and 'reclaiming sovereignty over the commodified terrain of patrol' (2006: 23). However, what makes Yar's insights so interesting is his reference to the expressive, rather than the instrumental conditions which prompt the need to keep things blue. This is now explored.

\section{Affective connectivities}

In his identification of a 'hierarchy of standing', Yar alights on something rather innovative in networked policing terms; that is, he foregrounds the importance to the dynamics of policing arrangements, of cultural values, affective intensities and public sensibilities. He notes, for example, that in light of the visceral passions (of outrage, hostility, intolerance, fear, hyperanxiety) which circulate public discourse of the policing of cyber-paedophilia - and, I would add, paedophilia more generally - 'policing cannot simply be surrendered to

the numbers of convictions the police had obtained through the use of covert investigations. He added that ' suspect the answer would be lower than you might expect. CEOP's covert investigation team was under five people' (Conlan, 2014). 
voluntarism, chance or the initiative of users, but rather ... the state should and must actively intervene to the full extent of its ability to tackle the problem' (2013: 492, original emphasis). Yar goes on to detail the range of legislative sanctions ushered in to combat cyber-sex offending and incapacitate offenders' access to internet sites. He points out the pre-crime (Zedner, 2007), as well as the post-crime logics of public policing's response; its ethos of zerotolerance; its demonstrative efforts to meet public expectation through commitments of resources, time, and manpower; and, more tellingly, its institutional investment in and operational prioritisation of online child protection, and the investigation of child sexual abuse imagery. While Yar stops short of suggesting the emergence of a moral panic, the emotional charge which ignites demands for authoritarian and punitive responses to especially reprehensible crimes is, nonetheless, very neatly captured by this well-rehearsed concept (Cohen, 1980[1972]; Hall et al, 1978) ${ }^{13}$.

We are reminded by Yar that affective power remains an important political dynamic in any account of the relationship between crime, and styles and modes of policing. We certainly learn from The Paedophile Hunter that digital vigilantism is tapping into, and identifies with an affective mood of public frustration and concern which, in many ways authorises, or at least justifies its raison d'être. Indeed, it is Hunter's belief that public policing is so 'bound by red tape' and starved of resources and funding, that responding to public concerns as a private citizen, is more important than doing nothing. At the same time, Hunter's methodologies harness the communicative power of social media to transmit the affective energies of his 'paedophile captures' in a way which connects with a viewing public united (albeit ephemerally) by shock, outrage, disgust and anger. Moreover, exploiting the fast flow of images across and through an infinitude of interconnected screens, Hunter ensures the public humiliation of his prey, creating hundreds of thousands of 'tiny theatres of punishment ..... (where) one may at each moment encounter as a living spectacle, the misfortunes of vice' (Foucault, 1977: 113-114). In other words, feelings, sentiment and desire - as much as customer service, statutory instruments, residents' committees and community consultations

\footnotetext{
13 It remains questionable whether a moral panic in its classic sense, has simply 'failed to launch' (Jenkins, 2009) in respect of contemporary paedophilia. In addition, over the last 20 or so years, critical re-thinking has questioned moral panic theory's reliance on a consensual model of society, its lack of objectivity, and its assumptions concerning the short-lived, aberrational, nature of public outrage (Ungar, 2001; Valier, 2002).
} 
- establish connections between styles of policing and their variegated publics. Attending to the ebb and flow of the affective connectivities which assemble and sustain the juxtaposition of different policing actors and sites, certainly re-orients our ontological focus, but it also challenges our preconceptions of how relationalities emerge and become established and recognisable as a policing configuration.

\section{Performative communities}

Yar is not the first or only scholar to figure the public as important interlocutors in debates concerned with the policing of paedophilia - although how they are figured is a moot point. Indeed, writing of the 'anti-paedophile' protests which erupted in the summer of 2000 in Paulsgrove, Portsmouth (UK), Drury (2002) reflects on how these local residents were constructed as a 'reactionary crowd' (ibid: 43) on a 'witch hunt' (ibid: 51 ); how their actions and speech were read through an 'interpretative repertoire of mob pathology' (ibid: 46); and how, through the skilful deployment of rhetorical devices and hyperbole, the public discourse (this public's discourse) was positioned outwith rational, authoritative commentary, and quickly delegitimised, disqualified and discredited ${ }^{14}$. Drury's incisive discourse analysis of the extensive media coverage which followed the Paulsgrove protests, alongside the comments and articulations of the residents themselves, went some considerable way to counter the very negative, if not downright hostile dismissal of these particular political voices. Moreover, he demonstrates very persuasively how, on closer inspection, the Paulsgrove protesters 'explained their own actions as a function of their antagonistic (meaningful) relationship with the police and authorities' (2002: 42) - a relationship, in this analysis, which cohered around questions of trust in policing, the security of family life, and the rights of children to be protected. What is important here is not the rationality or otherwise of the vox populi, nor even the substance of their discourse, but the recognition that 'the public' constitutes a key political constituency in policing matters. Such an acknowledgement is not lost on Hunter. Throughout the documentary 'Hunter's public' is represented less as a community in need of policing, but more as an audience whose interests are being served through his vigilante activities. Indeed, 'the public' in this context are recruited as active viewer-participants in the policing process - they are invited to approve of Hunter's work through Facebook shares,

\footnotetext{
${ }^{14}$ See also Wilson DC and Silverman I (2000) Innocence Betrayed: Paedophilia, the Media and Society. Oxford: Polity Press.
} 
make judgements on the dispositions of apprehended offenders through social media commentary, and contribute to his fund-raising ambitions.

Writing of the same events (the Paulsgrove protests), Ashenden's (2002) perceptive and critical discussion of the governance of paedophilia follows a similar line of inquiry concerning the role of the general public. Ashenden juxtaposes the loudly trumpeted introduction of (the then) new and extended police powers relating to paedophiliac offenders - as set out in the Sex Offenders Act, 1997, and the Crime and Disorder Act, 1998 (S2-4) - with the launch of the News of the World's ${ }^{15}$ infamous 'naming and shaming' campaign in the summer of 2000. She regards these developments as indicative of contemporary 'forms of vigilance attending paedophilia' (2002: 197) and notes how they map across two distinct models of political community which align with the Foucauldian concepts of the 'city-state' and 'Christianpastoral' approaches to governance - see Foucault, 1977, 1981, 1990. While the former supposes a political community populated by rights-bearing, juridical subjects bound to the polity by a social contract and the rule of law, the latter imagines a pure community where any 'monstrosity against natural and social order' (2002: 251) can be rigorously separated, rejected, politically disqualified, exposed and eliminated. For Ashenden, these political rationalities are reflected in, and refracted through a bifurcated response to the menace of paedophilia; and she notes the juxtaposition of a technical, administrative response focused on the protection of the public, the assessment and management of risk, and the containment (and rehabilitation) of dangerous individuals, with a populist, exclusionary and normalising impulse which seeks to expose offenders, expel danger and exorcise the paedophiliac threat from the community.

However, Ashenden persuasively demonstrates how these socio-political imaginaries are neither incompatible nor diametrically opposed, but intersect, overlap and are, in practice, mutually enhancing to the extent that certain illiberalisms, even within a policing regime

\footnotetext{
15 The News of the World was a national, red top (tabloid) Sunday newspaper which was published in the UK from 1843 to 2011. At points in its history, it was the biggest selling English language newspaper in the world; and at the time of its closure, it retained its place amongst the highest English language newspaper circulations. See Robinson, J (2011) 'News of the World to close as Rupert Murdoch acts to limit fallout', The Guardian. 7 July 2011. Found at: www.theguardian.com/media/2011/jul/07/news-of-the-world-rupert-murdoch. Accessed 20 November 2014.
} 
bound to the rule of law and due process, may be tolerated, if not overridden in the pursuit of child protection. She concludes that it is through their shared 'problematization of... the threat posed by paedophiles' (2002: 215) that distinct and alternative articulations of policing and community may be inscribed in complementary ways within and across multiple rationalities of governance. We can locate these overlapping and complementary dynamics in Hunter's and public policing's shared usage of covert, investigative techniques. Their difference rests more on the question of their relative capacities to employ such methods than it does on the matter of their (non)adherence to the rule of law and due process. Even if we may baulk at Hunter's more explicitly visceral approach, his careful and assiduous respect for evidence-gathering and preservation, and his working knowledge of the law, perfectly exemplifies Ashenden's (2002) identification of the co-existence and hybridisation of the moralising, exclusionary impulse of the 'pure community', and the technicist, administrative discourses of the citizen-state model of political community.

While Yar reminds us of the affective force of the 'public mood', Drury and Ashenden identify and acknowledge 'the public' as important political actors whose expressive and discursive capacities interact with, interrogate and potentially disrupt the normative contours of the policing landscape. Though Hunter makes a virtue of the recruitment of 'his public' as significant interlocutors, and fully exploits the interactional space of vigilante-public dialogue, the figural trope of 'the public' is rarely subjected to critical reflection in the plural policing literature. Where reference to 'the people' is made it is invariably through generic signifiers such as 'responsibilised citizens', 'rational consumers' and/or 'deliberative discussants'. Yet, in the context of paedophilia, and as Yar, Drury and Ashenden have astutely observed, 'the people' are always-already encountered as an active, embodied, performative and vocal force which articulates, and in some instances, brokers the political and moral boundaries of policing forms. We might, then, have expected 'the public' to be counted as a key constituency within the 'extended policing family' (Home Office, 2004), but their ambitions and aspirations for policing, and their frustrations, antagonisms, and sensibilities to how child safety and the protection of the community is being managed, are routinely condensed into statistical abstractions of 'needs, priorities, and preferences' (Home Office, 2004: 67), which render passionate voices mute. 


\section{The cultural public sphere}

Even so we would have to ask how policing-public dialogue is managed and mediated, and question whether (and how) Hunter's particular model of public engagement resonates with contemporary accounts of deliberative exchange in the public sphere. The multiplicity of technologies and micro-practices which constitute public policing's 'community engagement' work - such as customer satisfaction surveys, citizens juries, town hall meetings, hotlines, epetitions, 'have-your-say' events ${ }^{16}$, and everyday chats with community support officers seeks to elicit local views and gauge community opinion. Even if these methods of engagement achieved their stated aims, they are primarily associated with the public police and local authorities, and rarely feature within the corporate portfolios of non-state policing actors and agencies. Moreover, from the perspective of public sphere theory (Asen and Brouwer, 2001; Benhabib, 1996; Calhoun, 1992; Fraser, 1990; Habermas, 1989[1962]; Hauser, 1999), these kinds of communicative practices not only remain highly circumscribed in terms of their dialogical and demographic scope and reach, but operate at some distance from contemporary work which recognises that the form, content, style, locations and conditions of possibility for public deliberation and engagement is far more complex than the blunt tools of 'community consultation' will allow. There is no space here to unpack this extensive literature, but a particular strand of the scholarship seems especially pertinent to the present discussion. To recap briefly: collectively, Yar, Drury and Ashenden alert us to the affective, discursive and expressive dynamics of policing-public relations; and they demonstrate the ways in which normative questions concerning how, who and to what effect paedophilia is policed, are interpreted (made meaningful) through culturally inflected modes of expression, communication and interaction. For this reason, McGuigan's (2005) work on the public sphere as a fluid, cultural space which generates intersubjective understandings, and engages a heteroglossia of expressive forms, is especially instructive.

In a very eloquent article, he elaborates an account of the cultural public sphere which, he says, 'trades in pleasures and pains' (2005: 435) and works through the kinds of performative (aesthetic, affective, vocal, textual, embodied) modes of communication to be found in

\footnotetext{
16 One example of community-facing engagement work is the series of Have Your Say events organised by Northumbria Police, UK. See: www.northumbria.police.uk/news and events/news/details.asp?id=66891 Accessed 24 November 2014.
} 
everyday gossip, poetry, drama, popular and high art, television soap operas, newspaper columns, social networking sites, Hollywood film and reality TV, for example. In the context of the governance of paedophilia, the mediating role of the cultural public sphere is significant, and has certainly not gone unnoticed in the criminological literature (Grealy, 2014; Greer, 2003; Greer and Jewkes, 2005; Jewkes and Wykes, 2012; Kohm and Greenhill, 2011; Schofield, 2004). However, such communicative modes do not guarantee a politically palatable public dialogue. Indeed, McGuigan's suggestion that the cultural public sphere is as likely to mobilise a politics of uncritical populism as it is one of radical subversion, deliberative participation or conciliatory consensus, is telling. Understandably, then, academic commentary on the political value and politicising utility of cultural media, especially in relation to the governance of paedophilia, remains highly critical and circumspect.

On the face of it, Stinson Hunter's ability to 'set social media alight' and 'divide the country' (Denham, 2014) seems anathema to the promulgation of soberly and reflective debate in the cultural public sphere. Moreover, his penchant for self-publicity through his own social media channels, and his appearances on mainstream television and radio broadcasts, have something in common with the formats and tactics of the tabloid press, at least in their effects. Jewkes and Wykes, for example, complain of the sensationalism and exceptionalism which attends press coverage of paedophilia in the UK, Europe and the USA. They note how the preoccupation with the 'extraordinary event' ${ }^{17}$, and the 'celebrity event' ${ }^{18}$, serves to theatricalise the incidence of paedophilia, exaggerate the threat of 'stranger danger', overdramatize the narratives of child sexual abuse, and (ultimately) popularise its consumption in the form of voyeuristic infotainment. Lost from view is the 'ordinariness' of paedophilia and its embeddedness within the everyday domestic settings of the paternal family home (Saraga, 2001) - an 'ordinariness' which, and paradoxically, is buttressed by a popular culture which fetishizes youthful bodies and commodifies their sexuality through fashion, beauty, dieting

\footnotetext{
17 Examples here might include: the discovery of the Fritzl cellar (Austria, 2008); the rape and murder of Megan Kanka (US, 1994); the protracted and undetected offending, including kidnap, rape, torture and murder, of Marc Dutroux (Belgium, 1986-1996); the abduction and murder of Sarah Payne (UK, 2000).

18 For example, in the UK, there have been a significant number of arrests and convictions of a long procession of pop stars, TV presenters, a sports commentator, and a celebrity publicist, all of whom were 'household names'. These include Gary Glitter, Jonathan King, Stuart Hall, Max Clifford and Rolf Harris. Much of the contemporary 'celebrification of paedophilia' has been triggered by the posthumous revelations of the prolific and exponentially disturbing offending of Jimmy Savile. Though it is impossible to quantify the extent of his offending, it has been described as at an 'unprecedented scale' and likely to have involved at least 300 victims (BBC News, 2012).
} 
and art (Greer and Jewkes, 2005). As Jewkes and Wykes note, there is a 'cultural hypocrisy' (2012: 940) at work here whereby we may be simultaneously `enthralled - anguished, enticed, bombarded - by the spectacle of the sexual child' (Adler, 2001: 209 cited in Jewkes and Wykes, 2012: 940-941). At the same time, they observe the escalating cultural anxieties and 'panic about paedophiles in cyber-space' (Jewkes and Wykes, 2012: 934). Since the publication of their paper, the commonplace of press exposés of cyber-communities of paedophiliac offenders has been marked, alongside the increasingly routine use of triumphalist publicity for, and reportage of the investigative work of specialist (public) policing units such as the Child Exploitation and Online Protection Centre's (CEOP) (Yar, 2013). Collectively and cumulatively, the political and discursive effects of these representational practices work to re-orient our grasp of the locus and nature of the problem of paedophilia, and to misdirect our sense of where policing priorities might lie. It is little wonder that Jewkes and Wykes remain pessimistic, and conclude that:

The journalistic focus on dangerous strangers is diversion enough but in many ways the turn to 'cyber' is more insidious as it treats ... (virtual offending) ... more seriously than offending realities, diverts attention and resources away from real crime, and legitimates significant attempts to control and monitor new communications technologies with implications for the personal freedoms, privacies and human rights of all of us (2012: 946).

I am extremely sympathetic to their analysis, but I am not persuaded by it as a basis to either condemn outright Hunter's dialogical practice, or to reject the representational and communicative power of the cultural public sphere more generally. I explore these two issues in turn. Firstly, despite its superficial alignment with more salacious media styles, it is difficult to unequivocally characterise Hunter's media strategy as sensationalising or exceptionalising. While his work has certainly been sensationalised, not least by the production of a widely publicised documentary film, it is not clear that Hunter himself attempts anything more than to visually and discursively capture the social relations of 'the hunt' in real time. With no recourse to special effects or supplementary imagery, and without the need to meet editorial thresholds of newsworthiness, Hunter's representational style is relatively modest and amateur. If anything, he reinforces the ordinariness of paedophilia; that is to say, Hunter's 
uploads to his Facebook page amount to nothing more than a repetitive visual and textual narrative of the mundane settings and prosaic routines of paedophiliac offending. There is no celebrity icon or exceptional event to record, so much as the grubby doings of malign (usually) men who could be anybody's brother, neighbour, friend or employee. Operating from the privacy of their own homes, these unremarkable figures are regularly confronted and apprehended in a range of humdrum locations - cafés, shopping malls, railway stations and car parks. At the same time, in the moment of successful 'paedophile capture', the artificial distinction between cyber- and real-world offending, which so vexes Jewkes and Wykes, collapses under the weight of existential realities.

On the matter of rejecting the communicative power of the cultural public sphere more generally, an alternative and more progressive view of cultural media is found in Kohm's and Greenhill's (2011) analysis of the filmic representations of paedophilia in Anglo-European and North American films. For these authors, the spectre of the paedophile which haunts news discourse and cinematic narratives, functions `as a cultural blank space onto which various debates about the nature and shape of justice become inscribed' (2011: 196). The key point here is that these 'various debates' can engage (even confront) audiences with challenging questions and critical perspectives which may disrupt existing commitments to and beliefs about particular modes of governance. On this view, the politics of representation are far more complex and nuanced than Jewkes and Wykes allow. Modes of expression proliferate in a contemporary cultural public sphere which is marked by its multi-media formats and transactional connectivities. In such a context, public deliberations about paedophilia and its policing cannot be assumed as always-already conservative and populist, any more than they can be expected to be critical and progressively enlightened.

Judged by conventional criteria of who counts as a policing actor, and what constitutes a 'proper' policing style, it is unlikely that digital vigilantism in the form of paedophile hunting would pass a test of legitimacy. Yet, when assessed through the lens of its cultural conditions of possibility, the prospects for such an approach to 'take hold' within existing policing configurations appear to be far more equivocal. Though without legal or moral authority, this particular brand of digital vigilantism claims an affective authority which, it turns out, can be fully accommodated within a liberal-democratic framework committed to due process and 
the rule of law. We learn from Ashenden (2002) that far from being out-lawed, when it comes to child protection, the hybridisation and co-existence of policing forms, and the bifurcated political imaginaries they represent, is made possible. None of this takes place outwith public scrutiny and debate. Though there are good reasons to reject the deliberative power of the cultural public sphere, especially when it is channelled through an affective register of fear, anxiety, disgust and outrage, how such a cultural politics is represented, argued, organised and managed at the interface of policing-public relations remains an empirical question. In the next section, I want to propose a way forward which theorises the emergence of this particular brand of digital vigilantism. We can certainly acknowledge the contemporary proliferation of these citizen-led practices and vigilantly document their effects; but accounting for how they acquire leverage and make their presence felt within a heterogeneous assemblage of (authorised) policing actors, sites and technologies, requires some conceptual labour. Assemblage thinking provides an entry point.

\section{Assemblage theory}

In opening up a theoretical conversation, I want to return briefly to Yar's assertion that the governance of cyber-paedophilia has 'come to exemplify' (2013: 488) the shift to networked, pluralised modes of policing. In support of his claim, he refers to Wall's concept of a 'multitiered order-maintenance assemblage of networks and nodes of security' (2007: 159 cited in Yar, 2013: 488); and, as I have detailed above, he goes on to describe the heterogeneous elements which compose this assemblage, providing an inventory of the user-groups, domain administrators, internet service providers, security agents, non-governmental agencies, and public policing units which make up the networked governance of online sexual offences. What is missing from Yar's account, and which seems to me to be the defining feature of the concept of 'assemblage' is an alertness to the processes of assembly.

On the face of it, there is good scope here to make sense of contemporary policing through the lens of assemblage theory which has become synonymous with work concerned with convergence, exchangeability and networked life (DeLanda, 2002, 2006; Deleuze and Guattari, 1987; Latour, 1993). Assemblage thinking has certainly gained wide currency across 
the social sciences, the arts and humanities, as well as within criminological work more broadly (Campbell, 2013; Gray, 2013; Haggerty and Ericson, 2000; Maurutto and HannahMoffat, 2006). Yet, it has a very marginal presence within policing studies, and is all but invisible from scholarship focused on pluralised policing forms. With its focus on processes of becoming, rather than states of being, assemblage theory moves us away from normative, explanatory and descriptive accounts of networked policing which presuppose a specific configuration of bodies, spaces, and things - Loader's (2000) discussion of pluralised policing arrangements is typical of such accounts - toward a focus which concedes only a surface of potentiality for emergent relationalities, and looks for policing in the density and texture of things in their particularity; the affects, the technologies, the bodies, the events' (Stewart, 2004: cited in Marcus and Saka, 2006: 105). So, rather than attend to security arrangements which are already in place, assemblage thinking gives priority to how 'things' come to be arranged through their material and expressive capacities for interaction and interconnectivity such that new policing alignments, encounters and collaborations are created. Putting this another way, an assemblage approach asks ontogenetic questions rather than ontological ones, and in so doing it keeps us alert to the emergence of novelty, and the unexpected - that is, to forms and styles of policing which are unstable and problematic, and leave us with something else to explain.

Accounting for digital vigilantism within such a framework helps us to recognise what Delanda (2006: 12-16 ) refers to as its 'capacities for interaction' with existing policing forms. These do not inevitably arise from formalised agreements or planned policy initiatives but, as we have seen above, can emerge and 'take hold' through relations of affect, imaginaries of political community, and culturally-mediated dialogical praxis. In other words, assemblage thinking encourages an openness to who and what counts as a 'component element' of any given policing network, and how `an experimental matrix of heterogeneous elements (and) techniques' (Rabinow, 2003: 56) comes into being. At the same time, assemblage theory recognises that the connective tissues of policing assemblages are performatively - visually, affectively, materially, discursively and aesthetically - enacted through the policing labour that is actually undertaken - that is, in the doing, rather than in the thinking of policing. For all that, as Delanda notes ' $(\mathrm{t}$ )he identity of any assemblage at any level of scale is always the product of a process .... and it is always precarious, since other processes ..... can destabilize 
it' (2006: 28). This notion of impermanence and instability is certainly traced through the case study where any claim that digital vigilantism is permanently exiled from assembling with 'policing proper', is subject to ongoing processes of (de)coding and (de)territorialization. For example, the matter of how Hunter is coded - as an 'investigative journalist', a 'jobless jailbird' or a 'paedophile hunter' - and where his style of policing is positioned - in/out of the 'blue policing fold' - reminds us that policing networks are fluid, unstable, ephemeral, contingent and indeterminate. Even those which claim high degrees of stabilization - such as Interpol are susceptible to re-alignment and dis-assemblage.

\section{Concluding comments}

The argument I have developed over this paper is to regard the policing of paedophilia as a working surface or, in assemblage terms, as a space of potentialities for how policing practice can emerge and evolve within a pluralised landscape of multiple policing forms. Talk of digital vigilantism in the form of 'paedophile hunting' is beginning to circulate within contemporary discourses of how paedophilia can be policed. In this sense, the emergence of digital vigilantism defines an open and fluid space in which policing is continually in the making', and it marks an important occasion for thinking how policing can be elsewhere and otherwise. I have drawn a thumbnail sketch of assemblage theory here, less to undermine or argue against existing accounts of networked policing, but more to provide a conceptual vocabulary for talking and thinking about pluralised formations in ontogenetic rather than in ontological ways - ways which ask how they come into being, rather than of what they are composed. The case study cast a spotlight on the cultural energies and social practices which go into their assembly, traced through the work which Hunter actually performs and what it does; how his agency as a policing actor is rendered visible and knowable; and how it is narrated and coded. Moreover, Hunter optimises the use of digital technologies, as well as the public stage of TV appearances, radio interviews, a website, and a documentary film, to make connections with distant and proximate others via a cultural public sphere which harnesses and generates intensive relations of affect which link the fears of an anxious public to the desires of paedophiliac offenders, and the frustrations of other (beleaguered) policing actors. Nonetheless, if Hunter's brand of digital vigilantism is to connect with wider policing 
assemblages, it comes with both 'affordances and risks' (Tan, 2012); that is, it poses several 'risks' to consensual, accountable and legitimate policing, while its 'affordances' should not rely on its proven effectiveness in apprehending paedophiliac offenders. Resolving such issues is, however, a matter of political and ethical judgement which assemblage approaches are ill-equipped to either prescribe for or inform. As Savage complains, assemblage offers a 'politics of surface descriptors' (2004: 170) which may help us to map emergent and contingent lines of connection, and to understand how novel policing practices align and interact with established policing forms, but which remain inattentive to the power dynamics of these processes. Put bluntly, assemblage theory lacks the conceptual wherewithal to grapple with the power relations of emergence, and provides no evaluative or normative criteria to adjudicate the political fallout of policing configurations 'in the making'. It may well be that digital vigilantism is only fleetingly assembled as a policing formation and is unlikely to be(come) stabilised within 'policing proper'. In the meantime, we should be vigilant of its potential to disrupt settled habits and practices in ways which not only hybridise and blur the boundaries of acceptable and legitimate policing within liberal democratic societies, but also trouble our sense of where, with whom, and by what means, core principles of consent, accountability, and justice, may be located.

\section{Acknowledgements}

An earlier version of this paper was presented at the Decentring Security: Building and Policing Communities at Home and Abroad Workshop, held at the Center for British Studies, University of California, Berkeley, in December 2014. The workshop was funded by the Mellon Foundation. I benefitted greatly from the many stimulating discussions over the course of the workshop day, and I am very appreciative of the other contributors' helpful feedback and critical commentary on my paper - Adam Edwards, Ian Loader, David Betz, David Chandler, Louise Westmarland, Rita Abrahamsen, and Mark Bevir. I would also like to thank the anonymous reviewers of Crime, Media, Culture for their careful and constructive readings of the paper, and for their guidance and suggestions for improving and sharpening the structure and argument. 


\section{References}

Adler A (2001) The perverse law of child pornography. Columbia Law Review. 101(2): 209273.

Asen R and Brouwer DC (eds)(2001) Counterpublics and the State. Albany: State University of New York Press.

Ashenden S (2002) Policing perversion: the contemporary governance of paedophilia, Cultural Values. 6(1 and 2): 197-222.

Barford V (2013) Who are vigilante group Letzgo Hunting? BBC News. 19 September 2013. Available at: www.bbc.co.uk/news/magazine-24143991 (Accessed 29 November 2014).

Batchelor, T (2015) Paedophile hunters Dark Justice 'trap $20^{\text {th }}$ child sex pervert' and that's just a start. Daily Express. 9 July 2015. Available at: www.express.co.uk/news/uk/590013/DarkJustice-paedophiles-evading-capture-police-budget-cuts (Accessed 7 November 2015).

Bayley DH and Shearing CD (2001) The New Structure of Policing. Washington DC: The National Institute of Justice, US Department of Justice.

BBC News (2012) Jimmy Savile abuse claims: police pursue 120 lines of inquiry. BBC News. 9 October 2012. Available at: http://www.bbc.co.uk/news/uk-19887019 (Accessed 29 November 2014).

Benhabib S (1996) Critique, Norm and Utopia. New York: Columbia University Press.

Booth R (2013) Vigilante paedophile hunters ruining lives with internet stings. The Guardian. 25 October 2013. Available at: www.theguardian.com/uk-news/2013/oct/25/vigilantepaedophile-hunters-online-police (Accessed 29 November 2014). 
Booth R (2014) Paedophile hunters: the vigilantes taking the law into their own hands. The Guardian. 11 November 2014. Available at: www.theguardian.com/uknews/2014/nov/11/paedophile-hunters-vigilantes-peter-mitchell-derby $\quad$ (Accessed 29 November 2014).

Calhoun C (ed)(1992) Habermas and the Public Sphere. Cambridge, MA: MIT Press.

Campbell E (2013) Public sphere as assemblage: the cultural politics of roadside memorialization. British Journal of Sociology. 64(3): 526-547.

Channel 4 (2014) The Paedophile Hunter. Channel 4, aired on 1 October 2014.

Child Exploitation and Online Protection Centre (CEOP) (2011) Hundreds of suspects tracked in international child abuse investigation. CEOP Press Releases. 16 March 2011. Available at: www.ceop.police.uk/Media-Centre/Press-releases/2011/hundreds-of-suspects-tracked-ininternational-child-abuse-investigation/ (Accessed 29 November 2014).

Clark M (2005) The importance of a new philosophy to the postmodern policing environment. Policing: An International Journal of Police Strategies and Management. 28(4): 642-653.

Cohen S (1980 [1972]) Folk Devils and Moral Panics: The Creation of the Mods and Rockers. Oxford: Martin Robertson.

Conlan T (2014) The Paedophile Hunter: Channel 4 to air film on controversial web vigilante. The Guardian. 29 September 2014. Available at: www.theguardian.com/media/2014/sep/29/channel-4-paedophile-hunter-documentarystinson-hunter (Accessed 21 November 2014).

Connolly K (2010) Paedophile trap TV show backfires on presenter. The Guardian. 20 October 2010. Available at: www.theguardian.com/world/2010/oct/19/paedophile-entrapment-tvshow-germany (Accessed 29 November 2014). 
Crawford A, Lister S, Blackburn S and Burnett J (2005) Plural Policing: The Mixed Economy of Visible Patrols in England and Wales. Bristol: Policy Press.

Crawford A (2013) Computer-generated 'Sweetie' catches online predators. BBC News. 5 November 2013. Available at: $\underline{w w w . b b c . c o . u k / n e w s / u k-24818769}$ (Accessed: 21 November 2014).

Crump J (2011) What are the police doing on Twitter? Social media, the police and the public. Policy and Internet. 3(4): 1-27.

DeLanda M (2002) Intensive Science and Virtual Philosophy. New York: Continuum.

DeLanda M (2006) A New Philosophy of Society: Assemblage Theory and Social Complexity. New York: Continuum.

Denham J (2014) The Paedophile Hunter: Twitter reacts to vigilante Stinson Hunter in Channel 4 documentary. The Independent. 2 October 2014. Available at: www.independent.co.uk/arts-entertainment/tv/news/the-paedophile-hunter-twitterreacts-to-vigilante-stinson-hunter-in-c4-documentary-9769018.html (Accessed: November 2014).

Drury J (2002) "When the mobs are looking for witches to burn, nobody's safe": talking about the reactionary crowd. Discourse and Society. 13(1): 41-73.

Dupont B (2004) Security in the age of networks. Policing and Society. 14(1): 76-91.

Foucault M (1977) Discipline and Punish: The Birth of the Prison. Translated by Alan SheridanSmith. Harmondsworth: Penguin.

Foucault M (1981) Omnes et Singulatim: Towards a Criticism of Political Reason. In McMurrin S (ed) The Tanner Lectures on Human Values, Volume II. Salt Lake City: Univ. of Utah Press, pp 225-254. 
Foucault M (1988) Sexual morality and the law. In Kritzman LD (ed) Michel Foucault: Politics, Philosophy, Culture. Interviews and Other Writings, 1977-1984. London: Routledge, pp 271285.

Foucault M (1990) The History of Sexuality Volume 1: An Introduction. Translated by Robert Hurley. New York: Vintage Books.

Fraser N (1990) Rethinking the public sphere: a contribution to the critique of actually existing democracy. Social Text. 25(26): 56-80.

Gray, P (2013) Assemblages of penal governance, social justice and youth justice partnerships. Theoretical Criminology. 17(4): 517-534.

Grealy L (2014) Menacing Dennis: representing 'Australia's most hated man' and popular protests for policy change. Crime, Media, Culture. 10(1): 139-157.

Greer C (2003) Sex Crime and the Media: Sex Offending and the Press in a Divided Society. Cullompton: Willan.

Greer C and Jewkes Y (2005) Extremes of otherness: media images of social exclusion. Social Justice. 32(1): 20-31.

Habermas J (1989[1962]) The Structural Transformation of the Public Sphere: An Inquiry into a Category of Bourgeois Society. Translated by P Burger and F Lawrence. Cambridge, MA and London: MIT Press.

Haggerty KD and Ericson RV (2000) The surveillant assemblage. British Journal of Sociology. 51(4): 605-622.

Hall S, Clarke J, Critcher C, Jefferson T and Roberts B (1978) Policing the Crisis: Mugging, the State and Law and Order. London: Macmillan. 
Halliday J (2014) A snapshot of child abuse in the UK. The Guardian. 16 July 2014. Available at: www.theguardian.com/uk-news/2014/jul/16/operation-notarise-child-abuse-online-uknca (Accessed: 29 November 2014).

Hauser G (1999) Vernacular Voices: The Rhetorics of Publics and Public Spheres. Columbia: University of South Carolina Press.

Home Office (2004) Building Communities, Beating Crime: A Better Police Service for the $21^{\text {st }}$ Century. Cmnd 6360. London: HMSO.

Jenkins P (2009) Failure to launch: why do some social issues fail to detonate moral panics? British Journal of Criminology. 49: 35-47.

Jewkes Y (2010a) Much ado about nothing? Representations and realities of online soliciting of children. Journal of Sexual Aggression. 16(1): 5-18.

Jewkes Y (2010b) Public policing and internet crime. In Jewkes Y and Yar M (eds) Handbook of Internet Crime. Cullompton: Willan, pp 525-545.

Jewkes $Y$ and Andrews C (2007) Internet child pornography: international responses. In Jewkes Y (ed) Crime Online. Cullompton: Willan, pp 60-80.

Jewkes $Y$ and Wykes M (2012) Reconstructing the sexual abuse of children: 'cyber-paeds, panic and power. Sexualities. 15(8): 934-952.

Johnston P and Bartlett J (2014) How far should we go to stop online paedophiles? The Daily Telegraph. 13 November $2014 . \quad$ Available at: www.telegraph.co.uk/news/uknews/crime/11226166/How-far-should-we-go-to-stoponline-paedophiles.html (Accessed: 21 November 2014). 
Jones T and Newburn T (eds)(2006) Plural Policing: A Comparative Perspective. London: Routledge.

Kemshall H and Mclvor G (eds)(2004) Managing Sex Offender Risk. London: Jessica Kingsley.

Kohm SA and Greenhill P (2011) Paedophile crime films as popular criminology: a problem of justice? Theoretical Criminology. 15(2): 195-215.

Latour B (1993) We Have Never Been Modern. Cambridge, MA: Harvard University Press.

Loader I (2000) Plural policing and democratic governance. Social and Legal Studies. 9(3): 323345.

Marcus GE and Saka E (2006) Assemblage. Theory, Culture and Society. 23(2-3): 101-106.

Maurutto, P and Hannah-Moffat, K (2006) Assembling risk and the restructuring of penal control. British Journal of Criminology. 46(3): 438-454.

McFarlane C (2011) The city as assemblage: dwelling and urban space. Environment and Planning D: Society and Space. 29(4): 649-671.

McGuigan J (2005) The cultural public sphere. European Journal of Cultural Studies. 8(4): 427443.

Methven N (2014) Shocking moment self-styled 'paedophile hunter' confronts alleged sex attacker after posing as an underage girl. The Mirror. 30 September 2014. Available at: www.mirror.co.uk/tv/tv-news/shocking-moment-self-styled-paedophile-hunter-4346349 (Accessed 21 November 2014).

O'Malley P and Palmer D (1996) Post-Keynesian policing. Economy and Society. 25(2): 137155. 
Saraga E (2001) Dangerous places: family as a site of crime. In Muncie J and McLaughlin E (eds) The Problem of Crime. London: Sage, pp 191-239.

Savage, M (2004) Contemporary sociology and the challenge of descriptive assemblage. European Journal of Social Theory. 12(1): 155-174.

Schneider C and Trottier D (2011) The 2011 Vancouver Riot and the role of Facebook in crowdsourced policing. BC Studies. 175: 57-72.

Schofield K (2004) Collisions of culture and crime: media commodification of child sexual abuse. In Ferrell J, Hayward K, Morrison W and Presdee M (eds) Cultural Criminology Unleashed. London: Glasshouse Press, pp 121-131.

Stewart K (2004) Ordinary impacts: the affective life of US public culture. Unpublished manuscript, cited in Marcus and Saka, 2006

Tan L (2012) Museums and cultural memory in an age of networks. International Journal of Cultural Studies. 16(4): 383-399.

Thomas T(2005) Sex Offending and Society. Cullompton: Willan.

Trottier D (2014) Crowdsourcing CCRV surveillance on the Internet. Information, Communication and Society. 17(5): 609-626.

Ungar S (2001) Moral panic versus the risk society: the implications of the changing sites of social anxiety. British Journal of Sociology 52(2): 271-91.

Valier C (2002) Punishment, border crossings and the power of horror. Theoretical Criminology. 6(3): 319-337.

Wall DS (2007) Cybercrime: the Transformation of Crime in the Information Age. Cambridge: Polity. 
Williams R (2013) Who was Sweetie, the girl who trapped 1,000 paedophiles? The Telegraph. 6 November 2013. Available at: www.telegraph.co.uk/women/womens-life/10427382/Whowas-Sweetie-the-girl-who-trapped-1000-paedophiles.html (Accessed 21 November 2014).

Wood J (2006) Research innovation in the field of security: a nodal governance view. In Wood J and Dupont B (eds) Democracy, Society and the Governance of Security. New York: Cambridge University Press, pp 217-240.

Wyatt D (2014) 'Paedophile Hunter’ Stinson Hunter raises almost $£ 30 k$ for Kickstarter project. The Independent. 6 October 2014. Available at: www.independent.co.uk/artsentertainment/tv/news/paedophile-hunter-stinson-hunter-raises-nearly-30k-for-kickstarterproject-9777474.html (Accessed: 21 November 2014).

Yar M (2006) Cybercrime and Society. London: Sage.

Yar M (2013) The policing of internet sex offences: pluralised governance versus hierarchies of standing. Policing and Society. 23(4): 482-497.

Zedner L (2007) Pre-crime and post-criminology? Theoretical Criminology. 11(2): 261-281.

Biographical note: Elaine Campbell is Professor of Criminology at Newcastle University, UK. She researches and publishes on the spatial, aesthetic and performative dynamics of crime, punishment, policing and criminal justice, with a focus on how these are visually and discursively produced. She teaches courses in cultural criminology, everyday life, visual cultures and visual methodologies. 